\title{
Menjelang Masuknya Islam Di Ujung Timur Pulau Jawa
}

\section{Masyhudi}

Keywords: dispersal, assimilation, islam, culture, east java

\section{How to Cite:}

Masyhudi, nfn. (2007). Menjelang Masuknya Islam Di Ujung Timur Pulau Jawa. Berkala Arkeologi, 27(1), 31-42. https://doi.org/10.30883/jba.v27i1.941

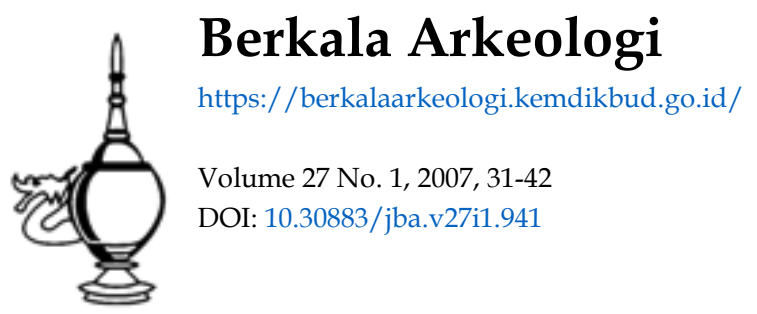

\section{(c) (i) (2)}

This work is licensed under a Creative Commons Attribution-NonCommercial-ShareAlike 4.0 International License. 


\title{
MENJELANG MASUKNYA ISLAM \\ DI UJUNG TIMUR PULAU JAWA
}

\author{
Masyhudi \\ (Balai Arkeologi Yogyakarta)
}

\section{Pendahuluan}

Pulau Jawa merupakan bentang lahan yang berada pada posisi yang sangat menguntungkan, yaitu posisi yang dapat membawa dampak akumulasi kultural dan politik yang datang dari berbagai arah. Hubungan yang terusmenerus antara Pulau Jawa dengan pulau-pulau lain bahkan negara-negara lain berakibat terjadinya akulturasi.

Sejak datangnya Islam di Nusantara yang ditandai dengan berbagai tinggalan arkeologis, baik yang bersifat monumental maupun yang non monumental, diantaranya sebuah makam kuna (tertua) yang terdapat di Gresik, yaitu makam Fatimah Binti Maimun dengan kronologi yang menunjuk angka tahun $1475 \mathrm{H} . / 1082 \mathrm{M}$, adalah suatu bukti adanya hubungan antara Jawa dengan negeri lain. Kemudian pada abad XIV Masehi, berpapasan dengan suatu kebudayaan besar yang telah menciptakan suatu sistem politik, nilai-nilai estetika, dan kemajuan kehidupan sosial keagamaan yang dikembangkan oleh kerajaan-kerajaan Hindu-Budha di Jawa (Geertz, 1968, 11-12).

Berkembangnya Islam di Pulau Jawa, baik di daerah pesisir utara Jawa maupun di beberapa daerah di pedalaman atau pegunungan dilakukan melalui berbagai strategi pendekatan yang ditempuh oleh para tokoh penyebar Islam (wali, ulama, maupun tokoh-tokoh lokal). Strategi tersebut meliputi; perdagangan, perkawinan, pendidikan, praktek-praktek mistisisme yang merupakan aktualisasi dari ajaran-ajaran tasawwuf. Setrategi tersebut dilakukan sesuai dengan tuntutan suasana, artinya memasukkan ajaranajaran Islam kepada masyarakat dengan memperhatikan kondisi sosialbudaya yang ada, sehingga kehadiran Islam dapat diterima dengan baik, tanpa adanya perlawana ataupun konflik.

Pada sekitar abad-14 Masehi, di Jawa telah diperlihatkan bukti mengenai kuatnya peranan masyarakat muslim, yaitu dengan hadirnya makam- 
makam kuna di Troloyo yang berangka tahun 1290 çaka atau $1368 \mathrm{M}$, (Kartodirdjo dkk, 1993 : 280) dan sekaligus sebagai bukti kemungkinan adanya masyarakat muslim di dekat pusat kerajaan Majapahit. Makammakam Islam di Troloyo berjumlah 21 buah, sebagian besar nisan-nisannya ditulis dengan angka tahun çaka. Nisan yang ditulis dengan huruf Arab hanya sebuah yang memuat nama tokoh yang dimakamkan, yaitu Zainuddin dengan angka tahun $874 \mathrm{H}$ (1469 M). (Damais dalam Kartodirdjo, dkk, 1993: 278).

Kemudian sejak abad-15 dan permulaan abad-16 Masehi, di beberapa daerah pusat perdagangan, yakni di Gresik, Demak, Cirebon dan Banten telah menunjukkan adanya kegiatan keagamaan yang diprakarsai oleh para wali di Jawa. Sementara itu pada pertengahan abad-16 Masehi, Demak yang pada waktu itu sebagai penguasa Islam di Jawa telah menaklukkan majapahit, dan kemudian sejak itulah perkembangan Islam di Jawa dapat berperan secara politis. Para wali dan tokoh-tokoh penyebar Islam telah dibantu oleh Demak sehingga dapat berperan dalam mensosialisasikan Islam, tidak saja di daerah-daerah penting di Jawa tetapi juga daerahdaerah pedalaman atau pegunungan di Jawa, termasuk daerah-daerah Jawa bagian selatan. Kabupaten Banyuwangi adalah suatu wilayah yang berada di ujung timur, Jawa Timur. Di daerah ini pernah terdapat sebuah kerajaan yang dikenal dengan sebutan Blambangan, sebuah kerajaan yang berlatar belakang agama Hindu. Pada abad XVI Masehi, Kerajaan Blambangan mengalami masa-masa perkembangan yang sangat mencolok dengan pusatnya di Banyuwangi. Ada kemungkinan lokasi pusat pemerintahannya Kerajaan Blambangan berpindah-pindah, diantaranya Purwa (alas Purwa) yang pada saat sekarang tidak berpenduduk, Umpak Songo, Tembokrejo, dan mungkin masih ada tempat lain yang belum diketahui.

Kerajaan Demak yang berlatar belakang agama Islam telah berupaya mengembangkannya sampai ke beberapa wilayah pedalaman Jawa Timur, namun upaya tersebut tidak semuanya berhasil, artinya tidak sepenuhnya wilayah pedalaman Jawa Timur dapat ditaklukkan atau diislamkan. Kemudian pada masa Kerajaan Pajang, yaitu sebuah kerajaan yang muncul setelah Demak mengalami keruntuhan. Kerajaan tersebut telah berupaya 
untuk menjalin hubungan diplomasi dengan beberapa daerah pedalaman di Jawa Timur, namun sayang usia Pajang tidak lama dan kemudian muncullah Kerajaan Mataram (Mataram Islam). Pada masa Mataram Islam, sejak Panembahan Senopati dan beberapa generasi berikutnya telah berupaya untuk menaklukkan beberapa wilayah di Jawa Timur. Upaya-upaya tersebut ternyata juga tidak dapat berjalan mulus, bahkan banyak rintanganrintangan yang harus dihadapi serta harus ditempuh melalui suatu perjalanan yang cukup panjang.

Dalam cerita rakyat di Banyuwangi, di daerah tersebut terdapat tokoh yang dikenal dengan nama Syekh Maulana Ishak (Syekh Wali Lanang) yang diaku sebagai salah seorang wali diantara sembilan wali penyebar Islam di Jawa. Tidak menutup kemungkinan tokoh tersebut juga memiliki peran yang cukup penting dalam perkembangan Islam di Banyuwangi. Di sisi lain, di Kabupaten Banyuwangi, Islam telah menunjukkan adanya suatu perkembangan yang sangat pesat, apabila dilihat dari.jumlah penduduknya. Hal demikian tentunya tidak akan terlepas dari para tokoh penyebar Islam. Berkenaan dengan hal tersebut, maka muncul suatu persoalan, bahwa sejak kapankah Islam berkembang di Banyuwangi?

Melalui tulisan ini, diharapkan dapat membatu memecahkan persoalan tersebut, terutama dalam kaitannya mengungkap sejarah Islam di Banyuwangi. Tentunya hal inipun harus dilakukan dengan suatu pendekatan yang semaksimal mungkin untuk dapat membantu memecahkan permasalahan yang dihadapi. Oleh karena itu dalam sajian ini akan diterapkan suatu pendekatan Historical Archaeology, yang dimaksudkan untuk mengungkap sejarah atau peristiwa masa lalu berdasarkan budaya materinya (material culture).

\section{Strategi Sosialisasi dan Perkembangan Islam di Jawa}

Secara ideologis sosialisasi Islam telah meninggalkan Al-Qur'an dan AsSunnah, sedangkan secara fisik telah memperlihatkan unsur-unsur budaya Islam sebagai unsur-unsur budaya yang berkesinambungan dari unsurunsur budaya pada masa sebelumnya sebagai langkah adaptasi untuk mencapai hasil yang maksimal (Ambary, 1991:1). 
Sikap adaptasi yang tercermin pada unsur-unsur budaya yang berkesinambungan tersebut dapat dilihat pada tata-cara pemakaman Islam di Jawa, dimana gunung merupakan tempat yang dianggap suci, sehingga pola penempatan bagi seorang tokoh yang paling dihormati ditempatkan di bagian paling tinggi. Demikian halnya dengan bangunan masjid yang berfungsi sebagai tempat melayani segala bentuk kegiatan keagamaan adalah bersifat dogmatis, religius, serta merupakan tuntunan pelaksanaan ajaran Islam yang berhubungan dengan konsekuensi ummat sebagai muslim. Hal ini menunjukkan bahwa kebudayaan manusia bukanlah basabasi yang pelaksanaannya hanya formalitas semata, tetapi di dalamnya mengandung berbagai pengertian fungsi masjid, yaitu masjid sebagai tempat ibadah, masjid sebagai tempat pertemuan antara manusia dengan nur ilahi, masjid sebagai kegiatan sosial, ekonomi dan lain sebagainya, (Rochym, 1983 : 155).

Selain itu proses Islamisasi di Jawa juga berlangsung melalui berbagai tradisi lisan dan babad-babad yang sebagaian besar menempatkan para wali (walisongo) pada posisi pertama dalam peran Islamisasi di Jawa. Nampaknya operasional para wali tersebut sebagian besar di daerahdaerah Jawa bagian utara, sedangkan upaya islamisasi di beberapa daerah di pedalaman dilakukan oleh mubaligh penerus para wali (orang-orang saleh) yang datang dari pesisir masuk ke pedalaman dengan satu tujuan, yaitu mengislamkan penduduknya. Diantara tokoh tersebut adalah Ki Gede Pandanaran atau dikenal dengan Sunan Bayat, (Lombard, 1996 : 125).

Sosialisasi Islam yang telah berlangsung sejak beberapa abad yang lalu adalah bermula pada kegiatan para wali yang kesemuanya pengikut suatu aliran mistik yang amat jelas coraknya. Meskipun dalam peng-Islaman di tanah Jawa merupakan sederetan peristiwa yang sangat kompleks, meskipun demikian Islam di daerah ini mampu memampatkan suatu periode panjang dari sebuah kerajaan besar, yaitu Majapahit, (Grunebaum, 1983 : 339). Sehingga sejak (akhir abad-15), Islam telah menggantikan Hinduisme di Jawa, yaitu dengan munculnya kerajaan Demak sebagai kerajaan terkuat di tanah Jawa dan merupakan senjata utama dalam kegiatan politik yang pada akhirnya sebagian besar masyarakat Jawa telah dapat di Islamkan (Dhofier, $1984: 12$ ). 
Selain itu, proses sosialisasi Islam yang dilakukan oleh para tokoh terdahulu juga dengan menggunakan lambang-lambang budaya dan lembaga pendidikan, sedangkan pendekatan yang digunakan dalam misi tersebut adalah pendekatan sinkretis, yaitu memanfaatkan lambang-lambang budaya dan lembaga-lembaga yang ada kemudian diisi dengan muatanmuatan ajaran Islam, sehingga mudah dicerna dan diterima oleh masyarakat awam. Dalam proses sinkretisasi ini, tidak hanya berlangsung pada bidang kognitif, tetapi juga pada tingkat perilaku, dan inipun akan dipandang sebagai sesuatu hal yang wajar, jika dipandang atau ditafsirkan melalui kacamata sinkretik.

Sebagai contoh yang dikisahkan dalam babad Tanah Jawi; bahwa kehadiran Nyai Rara Kidul, yang banyak diyakini oleh sebagian masyarakat Jawa sebagai makhluk halus, ternyata tidak menolak berhubungan dengan raja Jawa (Panembahan Senopati) atas bimbingan Sunan Kalijaga, sebagai seorang tokoh yang akan menetapkan Islam sebagai agama di Jawa. Dari sini dapat kita tarik suatu tafsir bahwa Islam dan pra Islam dapat bersatu di Jawa. Dalam konteks ini, relasi antara Panembahan senopati dengan Nyai Rara Kidul dapat dipandang sebagai elemen pra Islam (Jawa) dan di pihak lain Sunan Kalijaga sebagai elemen Islam.

\section{a. Perkembangan Islam di Jawa.}

Sosialisasi Islam di Indonesia berlangsung secara bertahap, meskipun antara satu tempat dengan tempat yang lain berbeda, yaitu tumbuhnya komunitas muslin, baik di daerah pantai maupun di daerah pedalaman. Dalam proses tersebut, perkembangan politik, ekonomi dan panggilan agama ikut tampil sebagai motivator yang ikut menentukan corak, penyebaran, pengembangan dan bentuk masyarakat muslim di setiap daerah tempat terjadinya sosialisasi. Di Jawa, proses tersebut berawal dari sepanjang pesisir utara yang pada waktu itu berperan sebagai jalur lalu-lintas perdagangan internasional dan sekaligus sebagai pusat penyebaran Islam.

Awal-mula terjadinya proses sosialisasi Islam di Jawa diprakarsai oleh orang-orang alim dan ahli di bidang agama Islam (para wali), dan para ahli agama yang tergolong ulama. Mereka tidak hanya datang dan menetap di 
kota-kota tetapi juga masuk ke daerah-daerah pedalaman, sehingga pada akhirnya proses persebaran Islam berkembang tidak hanya di kota-kota tetapi juga di daerah-daerah pedalaman atau daerah pegunungan. Meskipun demikian, proses yang ditempuh oleh para tokoh penyebar Islam tersebut tidak mudah serta memakan waktu yang cukup panjang, dimana pada masa pemerintahan sultan-sultan Demak sampai dengan masa pemerintahan Sultan Agung Mataram yang secara aktif melancarkan proses sosialisasi Islam, penuh dengan tantangan dan harus dilakukan secara bertahap.

\section{b. Islam di Pedalaman Jawa.}

Pada sekitar abad-17 - 18 Masehi, di Jawa telah terjadi pergulatan antara para penyebar Islam; pedagang, musafir dan ulama dan kaum sufi yang dampaknya semakin diakuinya peranan mereka dalam struktur komunitas pribumi, sehingga para tokoh tersebut dapat menduduki jabatan dalam struktur birokrasi kerajaan. Hal ini tentunya tidak terlepas dari strategi dakwah Islam yang dilakukan oleh para tokoh penyebar Islam tersebut, sehingga mereka dapat melakukan dakwah secara langsung kepada raja dan keluarganya, mendirikan masjid, mendidik kader ulama, serta pendekatan-pendekatan sosial yang sesuai dengan kondisi masyarakat setempat, (Ambary, $1998: 61$ ).

Pada abad-19 -20 yang dikenal sebagai puncak abad imperialisme merupakan masa keemasan bagi bangsa-bangsa yang bernafsu membentuk kekaisaran. Pada waktu itu Inggris, Perancis, dan bangsabangsa yang lain merajalela di Afrika dan Asia dengan mengancam negaranegara merdeka untuk dijadikan sebagai daerah kekuasaannya. Sementara itu Belanda jauh sebelumnya telah memulai politik ekspansinya. Namun di Indonesia, Belanda menghadapi kenyataan bahwa sebagian besar penduduk di kepulauan Nusantara yang dijajahnya adalah beragama Islam. Sementara itu Belanda merasa optimis untuk bisa secepatnya mengikis pengaruh Islam melalui kristenisasi. Hal ini didasarkan pada anggapan bahwa Islam di Indonesia, khususnya Jawa yang memang kuat sinkritismenya akan mudah ditaklukan.

Masalah sinkritisme Islam di Indonesia, terutama di Jawa memang cukup 
banyak disoroti. Snouck Hurgronje menyatakan, bahwa orang Islam di kawasan ini sebenarnya hanya nampaknya saja memeluk Islam dan hanya dipermukaan kehidupan mereka ditutupi oleh agama ini, ibarat berselimutkan kain yang penuh dengan lobang-lobang besar sehingga di dalamnya nampak keasliannya, bahkan sampai pada akhir abad-20, mayoritas masyarakat Jawa adalah abangan, yaitu hidupnya tidak sesuai dengan tuntunan formal agama (Niels Mulder, $1983: 260-267$ ).

Namun hal yang lebih penting adalah bahwa betapapun sinkretis dan abangannya masyarakaat Jawa adalah mereka tetap muslim, bahkan dalam kondisi demikian agama Islam merupakan kekuatan dinamik bagi masyarakat Jawa yang sebagian besar sebagai petani (hidup di daerah agraris).

\section{Sejarah Islam di Banyuwangi}

Dalam sosialisasi Islam di Jawa yang awal mulanya diprakarsai oleh para wali dan secara umum daerah-daerah yang dijadikan sebagi obyek Islamisasi adalah Jawa bagian utara (daerah pantai utara Jawa). Daerah ini merupakan daerah perdagangan sehingga strategi sosialisasi Islam yang dominan diterapkan pada saat itu adalah melalui perdagangan. Akan tetapi setelah kehidupan perdagangan orang Jawa mengalami kehancuran akibat upaya Belanda memonopoli perdagangan dan orang-orang Islam pada saat itu tidak dapat memainkan peran penting dalam percaturan politik di kota-kota, maka tindak lanjut penyebaran Islam ini digunakan setrategi dalam bentuk yang lain, yaitu melalui pendidikan di desa-desa (daerahdaerah pedalaman) Jawa, bahkan sampai di beberapa daerah di pegunungan selatan Jawa. Dalam fase ini bukan lagi peran para wali, tetapi sudah dilanjutkan oleh para tokoh ulama atau kyai dengan mendirikan masjid, surau ataupun pesantren di beberapa daerah pedalaman Jawa bagian selatan. Hal ini dapat dibuktikan melalui beberapa tinggalan arkeologi dan sejarah yang diduga kuat merupakan sisa aktivitas masyarakat di masa lalu, yaitu berupa makam, masjid, bekas bangunan pesantren dan naskahnaskah kuna, (Masyhudi, $2000: 33$ ).

Setelah runtuhnya sebuah kerajaan besar yang bernuansa Hindu, yaitu 
kerajaan Majapahit, dipandang sebagai akhir sebuah periode penting dalam sejarah. Peristiwa tersebut dipergunakan sebagai garis pemisah antara jaman kuna dan jaman baru dalam sejarah Indonesia. Dua kekuatan yang berhadapan adalah penguasa yang berkedudukan lama, yaitu Majapahit dengan kekuatan baru, yaitu barisan Islam (Kerajaan Demak) yang didukung oleh para ulama dari Kudus di bawah pimpinan Pangeran Ngudung. Setelah majapahit dapat ditaklukkan, berturut-turut Demak menaklukkan beberapa daerah di Jawa Timur, mulai dari Madiun pada tahun 1529 M, kemudian menaklukkan Medang Kamulan (Blora) tahun $1530 \mathrm{M}$, menaklukkan Surabaya tahun $1531 \mathrm{M}$, Pasuruan tahun $1535 \mathrm{M}$, Blitar tahun $1541 \mathrm{M}$, Gunung Penanggungan (sebagai benteng para elit religius Hindu-Jawa) tahun $1543 \mathrm{M}$, Malang pada tahun $1545 \mathrm{M}$ dan sebagai sasaran terakhir adalah Panarukan dan Blambangan, (Kartodirjo, 1987: 31).

Pada masa kekuasaan Mataram Islam, yaitu pada masa pemerintahan Panembahan Senopati tahun 1588 telah berupaya agar kekuasaannya diakui oleh raja-raja di Jawa Timur, namun upaya tersebut hanya dapat menundukkan di daerah Madiun. Kemudian pada tahun 1590, Raja Pasuruan yang namanya tidak dikenal, setelah di Islamkan oleh Demak, raja Pasuruan tersebut menaklukkan Blambangan pada tahun $1600 \mathrm{M}$.

Pada masa Pemerintahan Sultan Agung 1613 M -1646 M, Mataram pernah melakukan ekspansi ke beberapa daerah di Jawa Timur, yaitu pada tahun $1617 \mathrm{M}$ telah menduduki dan menguasai Pasuruan. Setelah jatuhnya Pasuruan, sejak itu pula pengaruh raja-raja Bali menguat kembali, bahkan sampai dengan 1632 M Raja Gelgel telah Menguasai Panarukan dan Blambangan. Pada tahun $1639 \mathrm{M}$ Mataram berupaya kembali untuk menaklukkan Panarukan dan Blambangan, dan akhirnya pada tahun tersebut Mataram telah berhasil menaklukkan Blambangan dengan sepenuhnya, (Graaf, 1985: 236).

Dalam Buku Nagari Tawon Madu, karya I Made Sujana disebutkan bahwa pada tahun 1546 agama Islam diperkirakan telah masuk ke daerah Blambangan, yaitu pada waktu Demak menyerang Panarukan dan sesudahnya guru-guru agama Islam menyebarkannya ke pedalaman yang pengaruhnya sampai dengan abad $18 \mathrm{M}$, dibuktikan dengan dipeluknya agama Islam oleh Pangeran Pati III dan Mas Wilis (Sujana, $2001: 7$ ). 
Dapat pula diperkirakan bahwa Islam telah masuk ke wilayah Blambangan pada tahun $1546 \mathrm{M}$, yaitu pada saat Demak berada di bawah kekuasaan Sultan Trenggono. Akan tetapi perlu di ketahui bahwa kronologi tersebut menunjukkan waktu pendudukan Demak terhadap Panarukan setelah jauh lebih dulu menaklukkan Pasuruan. Dan perlu diingat pula bahwa pada tahun itu Sultan Trenggonopun meninggal di Panarukan. Oleh karena itu kecil kemungkinannya Blambangan dapat ditaklukkan pada saat itu.

Berkenaan dengan minimnya data arkeologi yang berkaitan dengan sosialisasi Islam di di wilayah Banyuwangi, beberapa tempat yang diduga memiliki nilai historis justru menunjukkan kronologi yang lebih tua dengan peninggalan-peninggalan sebelum masa Islam (masa Klasik) yarig berlatar belakang agama yang berbeda, seperti di Alas Purwo, Tembokrejo, dan Umpak Songo. Sementara itu data arkeologi Islam menunjukkan kronologi yang jauh lebih muda daripada pendapat yang disampaikan oleh beberapa ahli sejarah. Data arkeologi Islam tersebut berupa sebuah naskah alqur'an kuna tulisan tangan dengan kolofon yang menunjukan angka tahun $1806 \mathrm{M}$.

Pada masa Mataram Islam, Banyuwangi merupakan daerah kabupaten, sebagai Bupati pertama adalah Wiraguna I (Mas Alit) yang berkuasa pada tahun $1773-1782$, (Utomo : 20). Nama Wiraguna dan Pangeran Alit juga terdapat di Kerajaan Mataram Islam, yaitu salah seorang putera Raja Mataram yang merupakan saudara kandung Sultan Amangkurat I, yang pernah melakukan pemberontakan terhadap istana pada tahun $1647 \mathrm{M}$, (Kartodirjo, 1987 : 160). Apakah ada keterkaitan antara nama Wiraguna sebagai bupati I di Banyuwangi dengan Wiraguna sebagai keluarga istana Mataram Islam? Sedangkan Sultan Agung, pada tahun $1639 \mathrm{M}$ telah berhasil menaklukkan Blambangan dengan sepenuhnya.

Strategi sosialisasi Islam di Jawa pada umumnya tidak terlepas dari strategi dakwah Islam yang dilakukan oleh para tokoh penyebar Islam, sehingga mereka dapat melakukan dakwah secara langsung kepada raja dan keluarganya, mendirikan masjid, mendidik kader ulama, serta pendekatanpendekatan sosial yang sesuai dengan kondisi masyarakat setempat, (Ambary, $1998: 61$ ). 
Sosialisasi Islam di Banyuwangipun tentunya tidak jauh berbeda dengan sosialisasi Islam di beberapa tempat yang lain, yakni melakukan dakwah secara langsung dengan penguasa dan keluarganya, mendirikan masjid, mendidik kader ulama dan lain sebagainya. Keberadaan masjid tertua di banyuwangi, menurut Sujana didirikan pada tahun 1840 M (Sujana, 2001 : 7). Berdasarkan informasi dari masyarakat, bahwa masjid pertama Banyuwangi didirikan atas prakarsa Bupati Banyuwangi I, kemudian masjid tersebut dipugar pada sekitar pertengahan abad ke- $19 \mathrm{M}$. Jika betul bahwa masjid tersebut didirikan oleh Bupati I, maka dapat diduga bahwa Bupati I sudah beragama Islam. Akan tetapi jika masjid tersebut didirikan pada tahu $1840 \mathrm{M}$ sebagaimana dikemukakaan oleh Sujana, maka keberadaan data arkeologi Islam terutama masjid adalah terlalu muda jika dibandingkan kronologi sejarah berkembangnya Islam di Banyuwangi.

\section{Kesimpulan}

Dari uraian tersebut di atas dapat ditarik suatu kesimpulan bahwa setelah Kerajaan Majapahit runtuh dan pusat kekuasaan beralih ke Jawa Tengah (Demak), maka bukan berarti bahwa pengembangan Islam di Jawa Timur terhenti sama sekali. Akan tetapi justru sejak saat itu proses sosialisasi Islam di Jawa Timur semakin meluas karena di sisi lain di daerah jawa Timur masih terdapat beberapa kerajaan kecil yang belum Islam, seperti Pasuruan, Panarukan, dan Blambangan. Hal itu dilakukan dengan kerjasama antara pusat-pusat pesantren yang juga semakin berkembang, (seperti di Surabaya, Gresik dan Tuban) dengan pusat kerajaan Islam di Demak, Jawa Tengah.

Pasuruan tunduk pada Islam pada tahun $1535 \mathrm{M}$, yaitu setelah Demak menyerang ke kota tersebut di bawah pimpinan Sultan Trenggono. Akan tetapi daerah-daerah lain yang belum Islam baru tunduk setelah muncul Kerajaan Mataram Islam, yaitu melalui peran Sultan Agung. Sultan Agung memiliki cita-cita untuk mempersatukan tanah Jawa, namun demikian harapan tersebut tidak mudah dicapai. Proses untuk pengislaman di Jawa Timur ditempuh dengan waktu yang sangat panjang. Banyaknya rintanganrintangan, baik dari dalam maupun dari luar, yaitu masalah perebutan kekuasaan, datangnya para penjajah yang ingin memonopoli perdagangan dan juga menguasai pemerintahan, yang kesemuanya menghambat lajunya 
pengembangan kekuasaan maupun Islam di Jawa pada umumnya. Namun demikian dengan mencari kelemahan-kelemahan para penguasa daerah, satu persatu beberapa daerah di Jawa Timur dapat di taklukkan , Tahun 1546 M Demak menaklukkan Panarukan, Tahun 1597 M, Blambangan dan Panarukan jatuh ketangan kerajaan dari Pasuruan yang sudah Islam dan Puncak kemenanagannya pada tahun $1600 \mathrm{M}$, dan Sultan Agung menaklukkan Blambangan dengan sepenuhnya pada tahun $1639 \mathrm{M}$ (Pigeaud, 1985:240).

Dengan demikian dapat diketahui bahwa Islam telah berkembang di wilayah Banyuwangi melalui beberapa tahap, sejak dari masa kekuasaan kerajaan Demak, pada pertengahan abad XVI M sampai pada kekuasaan Kerajaan Mataram Islam yang diprakarsai oleh Sultan Agung (abad XVII M).

Data arkeologi mengenai perkembangan Islam di daerah Banyuwangi sampai szat ini masih sangat sedikit yang diperoleh. Dan dari data arkeologi yang minim ini menunjukkan tidak adanya kesesuaian waktu dengan kronologi sejarah perkembangan Islam di wilayah Kabupaten Banyuwangi. Terkait dengan hal tersebut masih diperlukan penelitian atau kajian akademis di bidang arkeologi guna mendukung maupun mencari kebenaran sejarah perkembangan Islam di daerah Banyuwangi, dan secara umum untuk kepentingan membentuk maupun memperkuat jati diri bangsa. 


\section{KEPUSTAKAAN}

Al-Atas, Sayed Naquib, 1972 Islam Dalam Sejarah dan Kebudayaan Melayu, Kuala Lumpur: UKM

Ambary, Hasan Muarif, 1991, Makam-Makam Kesultanan dan Para Wali

Penyebar Islam di Pulau Jawa, Aspects of Indoneian Archaeology, No.12, Jakarta.

Dhofier, Zamakhsyari, 1984 Tradisi Pesantren, Jakarta: LP3ES

Damais, L. Ch, 957, Etudes Javanaise I. Les Tombes Musulmanen Datees de Tralaya, BEFEO, Tome XLVII, Fasc 2.

Geertz, 1968 Islam Observer, New Haven and London: Yale University Press,.

Graaf, H.J. De, 1987, Runtuhnya Istana Mataram, Jakarta: Pustaka Utama Grafiti.

Grunebaum, Gustave E. Von, 1983 Islam, Kesatuan Dalam Keragaman, Jakarta: Yayasan Perkhidmatan.

Lombard, Denys, 1996, Nusa Jawa Silang Budaya, Jaringan Asia, II, Jakarta: Gramedia, Pustaka Utama

Masyhudi, 2000, Sosialisasi Islam di Kawasan Pegunungan Selatan Jawa, Laporan Penelitian Arkeologi, Yogyakarta : Balai Arkeologi Yogyakarta

Niels Mulder, 1983, Abangan Javanese Religious Thought and Practice. Pigeaut, TH. G.TH., 1985, Kerajaan-Kerajaan Islam di Jawa, Grafiti Press, Jakarta.

Rachym, Abdul, 1983. Masjid Dalam Karya Arsitektur Nasional Indonesia, , Bandung: Angkasa.

Kartodirdjo, Sartono dkk, 1994. 700 Tahun Majapahit 1293 -1993 Suatu Bunga Rampai. Surabaya : CV, Tiga Dara.

Kartodirdjo, Sartono, 1987, Pengantar Sejarah Indonesia Baru 1500 1900), Jakarta: PT Gramedia

Sujana, I Made, 2001, Nagari Tawon Madu, Sejarah Politik Blambangan abad XVIII, Larasan Sejarah, Bali.

Utomo, H. Slamet, tanpa tahun, Tingkahe Wong Blambangan Ring Dongeng, Legenda Lan Sejarah Blambangan, 